In his earlier book, Dr. Monsarrat had referred to "the essential sv́vxuıs which is, for us, Nature itself".

How do assemblies and organization come about ? The author says, "I envisage the atoms as constructed of complementary power-units bound by their need for each other". This archetypal union gives us the clue to the simple formula at the end of the book by which the world may find issue from the ills which beset it. Dr. Monsarrat sees three ways lying open to the world: the predatory way, which is the way of competition, power-politics and grab ; the way of fear, which is the way of religion; and the way of grace, which is the way of science and intelligence. His formula for the way of grace lays down that individuals should "seek their own pleasure by discovering what will please their associates, and by giving them these pleasures".

It sciarcely needed the writing. of a new book to prove that if everyone were unselfish the world would be a happier place. What is really needed is a formula for the steady advance of mankind towards the actual practice of such unselfishness, and such a formula science has not yet produced, and indeed shows little prospect of producing. Surely it is foolish to expect such a formula from those who hold that man is merely a complicated molecular aggregate, and that an adequate account of his nature and dealings may be given by reference to the physical observables which he embodies. Man is different, and many of his specific differences are touched upon by Dr. Monsarrat in a way which brings home to the reader the fact that the author has not met with a full measure of success in complying with his own self-imposed critical canon of consisteney. He admits that certain individuals (metaphysicians, ore gathers) indulge in processes of abstraction the product of which is "fantastic"; he maintains that common-sense opinions issue from a haphazard survey guided only by desire; he points out that the preda. tory way and the way of fear have been the ways of choice for the greater part of the individuals in human history so far. There are then, and history shows that there always have been, trends of the whole individual which run counter to other trends of the same whole individual, and a monistic science cannot integrate these two sets of tendencies into a unitary framework, still less can it heal the conflict between them.

It is not clear what exactly the author conceives power-in-action to be, nor whether he understands power-not-in-action to be a possibility. In his earlier work he stated that the properties of an electron are wholly accounted for by its electrical charge, "electrical charge being a term we use to describe a particular sort of behaviour". There are still minds which reel at the thought of behaviour with nothing behaving, of action without an agent, or of patterning without something patterned, and it may be doubted. whether this book will dispel their last doubts. The author makes great use of the idea that the concept of power is derived from the fact that the individual's first, primitive and irreducible affirmation is an affirmation of himself as able and acting, but he neglects the fact that this is an affirmation, not of unsubjectivated acting, but of the self's own action$I$ am acting; $I$ am knowing.

With the best will in the world, I was unable to find that the numerous diagrams threw any light on the matter under discussion in the book.

J. LeyYester KING.
First Steps in Astronomy without a Telescope By P. F. Burns. Pp. $x+214$. (London: Ginn and Co., Ltd., n.d.) 5s.

THE late Sir Frank Dyson, when speaking on an educational platform, used to express his disapproval of the omission of so fascinating a subject as astronomy from schemes of science instruction in sohools. Nor was he satisfied with the reply that the skies are most attractive when children ought to be in their beds asleep, and that anyhow telescopes are not so easily come by as test-tubes. So much' is experimental work preferred to observation and calculation that, as the author of this book says, very few children leave our schools with even a fragmentary knowledge of the starry heavens and of the place of the earth in the universe. To those teachers who would like to remedy this defect Mr. Burns's book will at once appeal. In writing it he has had also in mind young people who are members of the A.T.C. or J.T.C., or who as guides and scouts study for the astronomer's or star-man's badge. The neods of adults also, who wish for guidance in the study of the heavens, have definitely determihed both the approach to, and much of the subject-matter of, this introduction to outdoor astronomy. The book is clearly written, carefully graduated, abundantly illustrated, and beautifully produced. It should take its place not only as a text-book, but also as a giftbook.

\section{Control of the Common Fevers}

By Twenty-one Contributors, arranged with the help of Dr. Robert Cruickshank by the Editor of The Lancet. Pp. vi+361. (London : The Lancet, ${ }^{*}$ Ltd., 1942.) 12s. 6d. net.

7 HIS is a book which will appeal to a large circle of readers, especially health officers and laboratory workers. The subjects discussed are diphtheria, streptococcal infections, scarlet fever, erysipelas, puerperal sepsis, rheumatic fever, pertussis, measles, the common cold, epidemic influenza, the pneumonias, enteric fovers, bacterial food poisoning, bacillary dysentery, gastro-enteritis, undulant fever, cerebrospinal fever, poliomyelitis, catarrhal jaundice, Weil's disease, small-pox and the Rickettsiases. The text is liberally interspersed with charts and diagrams, and a short bibliography of mainly British and American works is appended to all but one.(puerperal sepsis) of the chapters, while suggestions for further reading are made at the end of the book.

\section{A Handlist of the Birds of the Sevenoaks or Western District of Kent}

By James M. Harrison. Pp. xviii $+165+68$ plates. (London: H. F. and G. Witherby, Ltd., 1942.) 30s. net.

NR. HARRISON'S book is a large and detailed Work. The forty-one coloured plates are from good original water-colours by the author, and there are several half-tone and line illustrations.

The observations recorded are those of the author gleaned over a period of twenty years, correlated with those of as many other ornithologists as the author himself could discover, A bibliography, glossary of scientific terms and an index are appended. The work is necessarily specialized and will appeal mainly to those living in the west of Kent and to other British ornithologists. 